\title{
開空療法を適用した含歯性囊胞の予後に対する臨床的検討
}

\author{
依田寿幸・神谷祐司・神野洋輔・小牧完二 \\ 服部吉幸・吉田勝弘・山本信吾・河合幹 \\ 内藤宗 孝*
}

\section{Clinical study of marsupialization for dentigerous cyst}

\author{
Toshiyuki Yoda - Yuji KamiYa - Yohsuke Jinno \\ Kanji Komaki - Yoshiyuki Hattori - Katsuhiro Yoshida \\ Shingo Yамамото - Tsuyoshi KawaI - Munetaka NaItoH*
}

\begin{abstract}
We investigated clinical and radiographic findings after Marsupialization for eruption of impacted tooth in dentigerous cyst of the lower premolar region in 17 children. The results were as follows.

1. Eruption of the impacted tooth was confirmed in all cases.

2. The impacted teeth which had a tilt over 60 degrees erupted with twist postoperatively.

3. After marsupialization, the impacted tooth erupted faster than the normal tooth on the opposite side.

Marsupialization of cyst is very useful for eruption of impacted teeth in children.

Retaining the space for tooth eruption is necessary in patients whose impacted tooth locates deeply in the mandible, or occlusion is unstable.

It is necessary to correct the impacted tooth wis much tilt in the mandible by orthodontic treatment after marsupialization.
\end{abstract}

Key words: dentigerous cyst (含蒾性腱胞), marsupialization (開空療法), lower premolar (下 顎小臼料）

緒

$\overline{\overline{\bar{一}}}$

小児の含歯性擎胞に㧍いて原因となった埋伏永久歯の 保存を目的とした開空療法は, 1936年に Russel1)が報告 して以来多くの症例に適応され, その有用性は広く認め

带知学院大学歯学部第 2 口腔外科学教室

(主任：河合 幹教授)

* 愛知学院大学秚学部放射線学教室

（主任：菊地 厚教授）

The Second Department of Oral and Maxillofacail Surgery, School of Dentistry, Aichi-Gakuin University (Chief: Prof. Tsuyosi Kawai)

* Department of Dental Ragiology, School of Dentistry, Aichi-Gakuin University (Chief: Prof. Atsushi Kikuchi)

受付日：平成元年 5 月 17 日
られているところである。しかし，その適応において は, 個々の症例に颃いて埋伏歯の状態, 患者の年龄など の条件が異なるため, 慎重に検討される必要がある.

そこで今回われわれは, 当科にて処置を行った小見の 含歯性雚胞について, 術前, 術後のX線写真の検討を行 い，若干の知見を得たので報告する。

\section{対 象 症 例}

対象症例は，1981年 9 月より1988年 8 月までの間に当 科で処置を行い, 臨床的および, 病理組織学的にも, 濾 胞性歯雚胞と診断し得た17例の開空療法適用例である. な抏, 検索の条件を規定する必要から, 下顎の小臼歯部 に病変のみられた症例のみについて対象症例とした。さ らに, 術後に矯正力を加えた症例は今回の検索から除外 した。

対象症例の内訳は, 男性 7 例, 女性10例で年齡は 6 歳 
表 1 術前の状態と術後の経過

\begin{tabular}{|c|c|c|c|c|c|c|}
\hline \multirow[b]{2}{*}{ 症例 } & \multicolumn{5}{|c|}{ 術 } & \\
\hline & 年齢 & $\begin{array}{l}\text { 萌出 } \\
\text { 余地 }\end{array}$ & 根形成段階 & 大きさ & 傾斜度 & \\
\hline 1 & 6 & + & 形成初期 & $41 \sim$ & $0 \sim 30$ & \\
\hline 2 & 7 & + & 形成初期 & $21 \sim 30$ & $0 \sim 30$ & \\
\hline 3 & 8 & + & $1 / 4$ 形成 & $21 \sim 30$ & $\sim 30$ & \\
\hline 4 & 8 & - & $1 / 2$ 形成 & $21 \sim 30$ & $0 \sim 30$ & \\
\hline 5 & 8 & + & $1 / 2$ 形成 & $21 \sim 30$ & $0 \sim 30$ & \\
\hline 6 & 8 & + & 成初期 & $31 \sim 40$ & $31 \sim 60$ & \\
\hline 7 & 8 & + & 形 & $21 \sim 30$ & $\sim 30$ & \\
\hline 8 & 9 & + & $1 / 2$ 形成 & $21 \sim 30$ & $0 \sim 30$ & \\
\hline 9 & 9 & + & $1 / 2$ 形成 & $21 \sim 30$ & $0 \sim 30$ & \\
\hline 10 & 9 & + & $1 / 2$ 形成 & $31 \sim 40$ & $61 \sim 90$ & \\
\hline 11 & 9 & - & $3 / 4$ 形成 & $31 \sim 40$ & $61 \sim 90$ & \\
\hline 12 & 9 & + & $1 / 2$ 形成 & $11 \sim 20$ & $0 \sim 30$ & \\
\hline 13 & 10 & - & $3 / 4$ 形成 & $21 \sim 30$ & $0 \sim 30$ & \\
\hline 14 & 10 & + & $3 / 4$ 形成 & $21 \sim 30$ & $0 \sim 30$ & \\
\hline 15 & 10 & - & $1 / 2$ 形成 & $21 \sim 30$ & $31 \sim 60$ & \\
\hline 16 & 10 & + & $3 / 4$ 形成 & $21 \sim 30$ & $0 \sim 30$ & \\
\hline 17 & 11 & + & $1 / 2$ 形成 & $21 \sim 30$ & $31 \sim 60$ & \\
\hline
\end{tabular}

$\bigcirc$ : 萌出を認めた症例

○：迷軸の捻転を認めた症例

$\triangle$ : 明らかに, 萌出余地が減少した症例

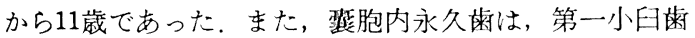
3 例, 第二小目歯10例, 第一第二小目歯の両方を含むも のが 4 例であった（表 1 ).

\section{手 術 方 法}

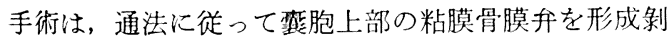
離した後，煩側歯槽骨を削除し萑胞壁を埋伏歯の歯頸部 付近まで可及的棌離し摘出した。

\section{$\mathbf{X}$ 線上での検索項目}

下記 7 項目について検索を加えてみた

\section{1 萌出余地}

萌出余地（両隣在歯間距離）を $\mathrm{A}$ ，雚胞内永久の料間 幅径を B とし，AとBの差により判定した。十分な萌出 余地が認められるものを十。AとBの差がないものすな わち萌出余地がないものを一とした（図1）。

\section{2. 歯根形成段階}

Moorrees $5^{2)}$ の分類汇従い歯根形成初期, $1 / 4$ 形成, $1 / 2$ 形成, $3 / 4$ 形成，歯根完成の 5 段階に分け検討した (図2).

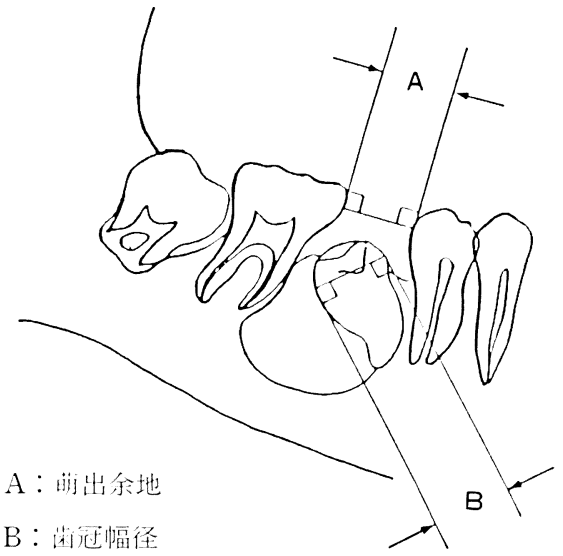

図 1 萌出余地の測定方法

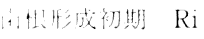

当恨 $1 / 4$ 形成 $\mathrm{R}_{1}$ ：

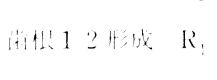

细恨 34 形成 $\mathrm{R}$
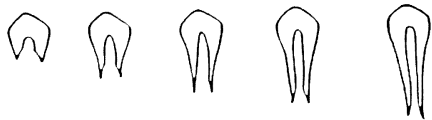

俚根完成 Rc
$\mathrm{R} \div \quad \mathrm{R} \frac{3}{4}$

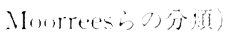

図 2 蓬根形成段階の基準

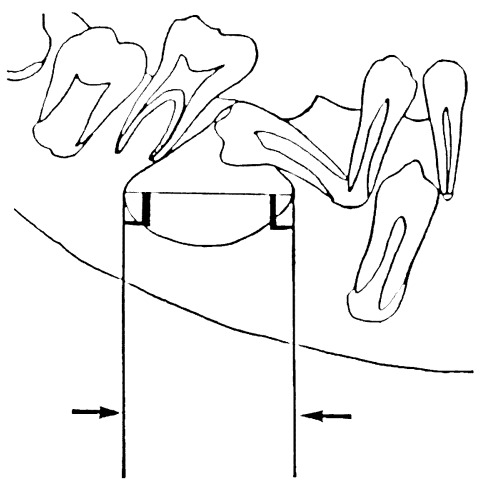

図３整胞の大き岂の测定方法

\section{3. 虽胞の大ささ}

初䧐時のX線ハノラマ断層写真上にて認められた透過 像の近遠心的最大幅径を整胞の大きさとした。またX線 写真の拉大率を一定と寸るため, 第一大四歯幽冠幅径を $15 \mathrm{~mm}$ と決め, 鿊胞の大きさを補正した（図了）.

\section{4. 原因埋伏歯の傾斜度}

初診時のX線パノラマ断層写真より, 患側の第一大曰 歯の歯軸之原因埋伏籸のな角度を $\mathrm{A}$, 健側の同名歯の

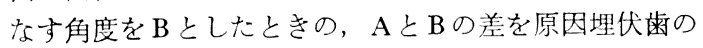




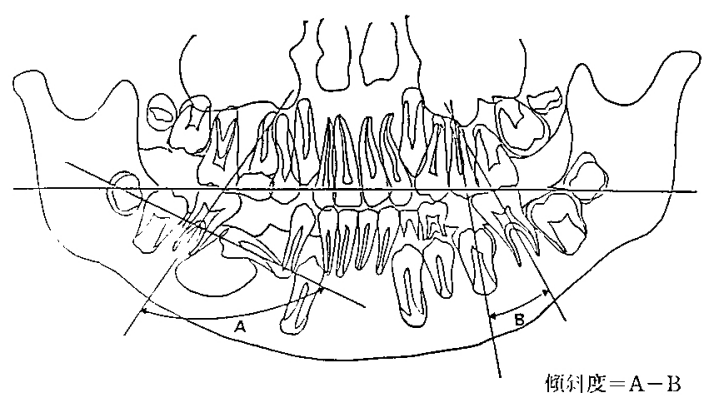

図 4 埋伏宷の傾斜度の測定方法

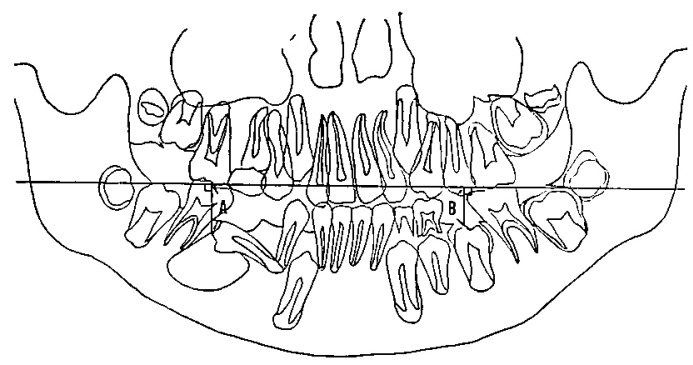

図 5 埋伏蒖出速度の測䇥方法

傾斜度とした（図 4)。なお，X線パノラマ断層写真上

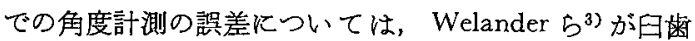
部で士 5 度程度であると報告しているので，われわれは この證差を考虑し，30度間隔で分類し解析を行った。 た，両側第一大臼雪の遠心咬頭を結んた線と第一大曰歯 のなす角度により両側第一大曰歯の角度を補正し，さら にこれより埋伏歯の角度を補正した。

\section{5. 術後の原因埋伏歯の状態}

術後の定期的に撮影したX楾パノラマ断㬝写真によ

り，原因埋伏齿の術後状態を観察した。

\section{6. 原因埋伏菌の萌出速度}

原因となった患側埋伏歯と健側同名歯の萌出速度をX 線パノラマ断圈写真にて下記の基準により比較した。

両側第一大田歯の遠心咬頭を結んだ線に対し，患側健 側の被検埋伏崡の咬頭より垂線を引き，術前術後におけ る垂線の長さ（距離）の美を求萌出速度の基準とし た。原因埋伏歯の方が早い萌出速度である場合を十，遮 い場合をーとした（図 5)。京た，健側同名歯が初診時 に完全萌出していた症例が 3 例あり，これらについて萌 出速度が求められないため除外した。

\section{7. 術後 $\mathbf{X}$ 線写真上での噻胞腔の骨梁および硬線の变} 化

術後X線写真上で，䘣胞腔の存在していた骨欠損部の 骨梁形成状態々覆胞境界部の硬線について観察した。骨 梁が健側と同様になり，覇胞の境界部に存在する硬線が

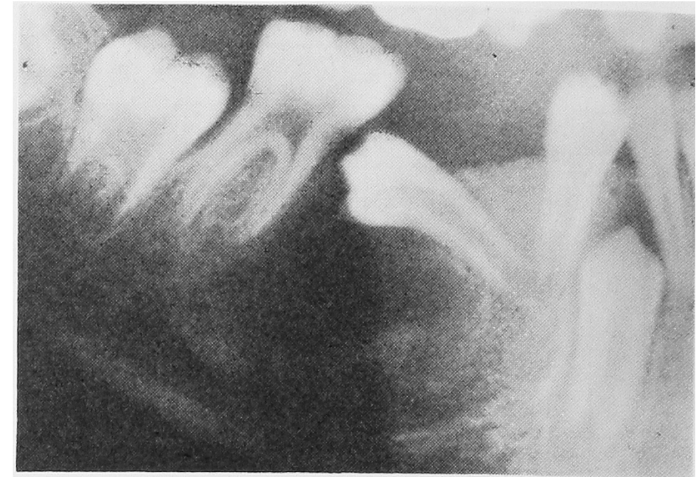

写真 1 症例 10 術後 1 か月のX線写真

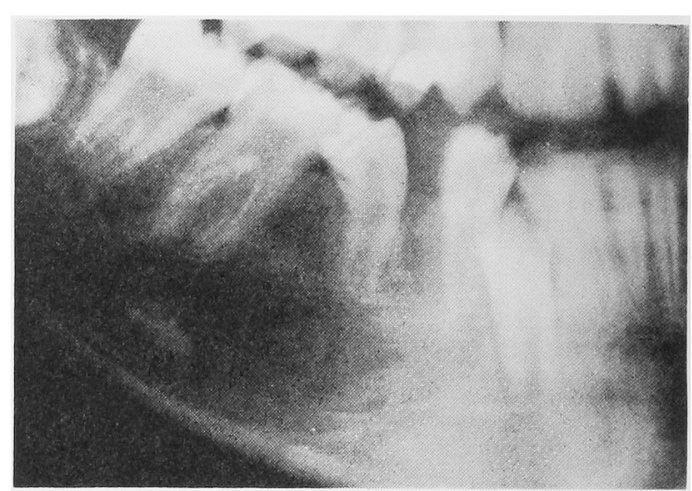

写真 2 症例10の法後 1 年 3 か月のX線写真

消失した時点を治癒とした。

結

果

1 萌出余地

十分な萌出余地の想められるるの $(+) 13$ 例，(-) のもの 4 例であった（表 1 ).

2. 歯根形成段階

術前歯根形成段階の 分布は，根形成初期 4 例，1/4 形成 1 例， $1 / 2$ 形成 8 例， $3 / 4$ 形成 4 例，歯根完成 0 例 であった（表 1$).$

\section{3. 術前の萌出余地および歯根形成段階と術後経過}

予後観察では，多少萌出余地不十分な症例でも，頻の 成長により萌出が可能になっでり，また埋伏歯怔根 未完成であればどの段階に打いても萌出した。一部症例 （症例 1）飞おいては，明らかに萌出余地が減少してい たが上下第一大曰歯が咬合しておらずその茵軸が傾斜し ていたためであった.

\section{4. 緟胞の大きさ}

䧸胞の大きさについては, $10 \mathrm{~mm}$ 単位で表した。 そ の分布は 11〜20 $\mathrm{mm}$ が 1 例, 21〜30 $\mathrm{mm}$ が12例，31〜 


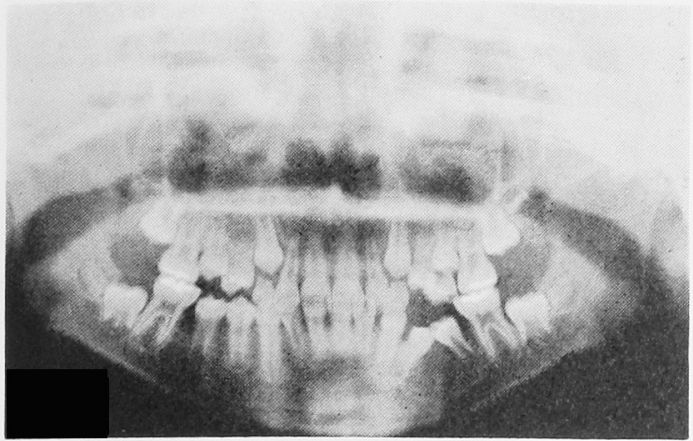

写真 3 症例11の初訩時のX線写真

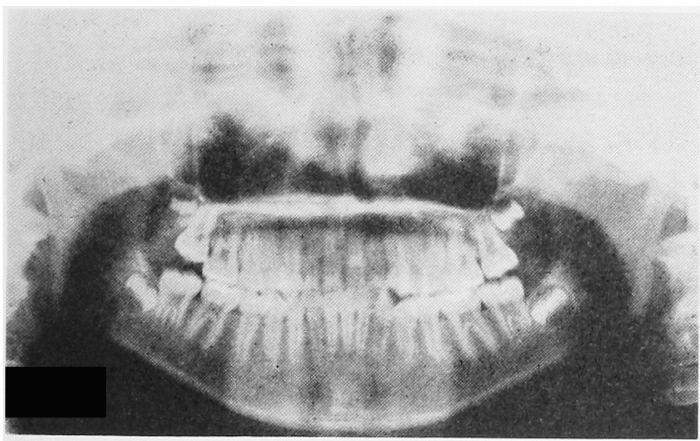

写真 4 症例 11 很後 2 年 5 か月のX線写真

$40 \mathrm{~mm}$ が 3 例, $41 \mathrm{~mm}$ 以上が 1 例であった（表 1 ）.

\section{5. 原因埋伏歯の傾斜度}

埋伏齿の倾斜度は， $0 \sim 30$ 度が 12 例，31〜60 度が 3

例，61〜90度が 2 例であった（表1).

\section{6. 術前の豪胞の大きさおよび原因埋伏歯の傾斜度と 術後経過}

衰胞の大きさが $0 〜 30$ 度の症例は，すべて問題なく萠 出した。

しかし，慗胞の大きさが $31 〜 40 \mathrm{~mm}$ と大きく，埋伏 崡の傾斜度が61 90度と大きい 2 症例においては，萌出 後蒾軸の捻転を生したた，症例10は術後 1 か月ではまだ歯 軸が大きく傾斜している(写真1). 術後 1 年 3 か月で は，埋伏歯の歯軸がほぼ直立して定位膡に萌出している が，歯軸の捻転を後遺した（写真2）.

症例11は初診時には原因埋伏歯が相当大きく傾斜して いる (写真了). 術後 2 年 5 か月纪は，症例10之同様に ほぼ定位置に萌出しているが，歯軸の捻転を後遗した (写真 4 ).

\section{7. 原因埋伏歯の萌出時期と萌出速度}

術後の埋伏歯と健側同名歯の萌出経過の違いを観察で きた症例は14例で, 萌出完了時期が埋伏齿のほらが早か ったものが 6 例，ほぼ同じであったものが 4 例, 荤かっ たものが 4 例であった（表 2 ）。ほぼ同じであった 4 例
表 2 萌出速度差

\begin{tabular}{|c|c|c|c|c|c|}
\hline 症例 & 年畧 & $\begin{array}{l}\text { 初骖X線写 } \\
\text { 真の健側同 } \\
\text { 名歯の状態 }\end{array}$ & $\begin{array}{l}\text { 初診時 } \\
\text { 位賢差 }\end{array}$ & $\begin{array}{l}\text { 街後の } \\
\text { 萠出差 }\end{array}$ & 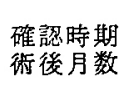 \\
\hline 1 & 6 & 未萌出 & $4 \mathrm{~mm}$ & \pm & 11か月 \\
\hline 2 & 7 & 未萌出 & 2 & 土 & 36 \\
\hline 3 & 8 & 萌 出 & & - & 3 \\
\hline 4 & 8 & 萌 出 & & - & 3 \\
\hline 5 & 8 & 未萌出 & 2 & + & 5 \\
\hline 6 & 8 & 未萌出 & 0 & + & 6 \\
\hline 7 & 8 & 末萌出 & 10 & \pm & 2 \\
\hline 8 & 9 & 完全萌出 & & & \\
\hline 9 & 9 & 未萌出 & 0 & + & 3 \\
\hline 10 & 9 & 未萌出 & 2 & + & 7 \\
\hline 11 & 9 & 未萌出 & 3 & \pm & 8 \\
\hline 12 & 9 & 未萌出 & 4 & + & 6 \\
\hline 13 & 10 & 完全萌出 & & & \\
\hline 14 & 10 & 完全萌出 & & & \\
\hline 15 & 10 & 未植出 & 0 & + & 15 \\
\hline 16 & 10 & 萌 出 & & - & 3 \\
\hline 17 & 11 & 萌 出 & & - & 3 \\
\hline
\end{tabular}

萌出時期が原因埋伏菌の汪 5 が

早い: + 同じ：土 遅い：-

は, 初診時に, 原因埋伏歯の方が $2 \sim 10 \mathrm{~mm}$ 低位に存在 したにあかかわらず，萠出完了時期が同しであったこと から，患側埋伏崡の萠出速度の方が相当に速いことがわ かる，また，遅かった（一４例は，術前すでに健側同 名雨が成上飞一部萠出していた症例であり，この場合 も原因埋伏歯の術後における実際の萌出速度は健側同名 歯に比へて速いといえる。すなわち開空手術によって原 因埋伏歯は，萌出速度が速くなることが示唆された。

\section{8. 病変部の治痖過程の観察}

治㭸状態の判定については, 骨梁の形成之巽胞周囲の 硬線の消失をみた時点で治癒と判定した，術後のX線写 真にて, 全例正常の骨梁の形成を確認しているが, 経過 観察の期間が症例によって異なり，術後 6 か月から 1 年 で骨梁の確認できた症例は17例中10例であった．他の 7 例はこの期間㳊過観察できなかった症例であるが，そ の後の観察で骨梁の形成を確認をしている.

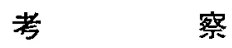

含歯性变胞の原因埋伏歯の保存を目的とした開空潦法

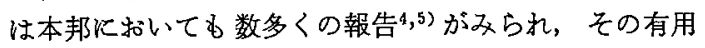
性は広く認められているが，原因埋伏電の位置，植立方 向，整胞の大ささなどの条件によって適用の判断に迷わ されることがしばしばある。また，術後の経過観察にお。 
ける評価や保隙装置を含めた矯正治療の適用等について も悩むことが多い。この点に関して最近富永ら ${ }^{6)}$ は, 捛 胞の形成状態を Thoma ${ }^{7}$ の分類に従い中心型と側方型 に分け，側方型では矯正装置の㐼用を前提とすべきであ るという興味ある報告をしている。

今回われわれも，開空療法の適用限界および，術後の 評洒法を探るべく症例検討を行ってみた。検討にあたっ ては対象症例を下顎小曰菌部に限定して，条件の統一を はかった。 また，同様の意味で矯正的外力を加えた症例 も，対象から除外乙経過観察を行った。

萌出余地は埋伏歯の保存の適否を決定する最も重要な 要因といわれているが，今回のわれわれの症例では，必 ずしも十分な萌出余地を持たなくとも著しい㦈生もなく 完全萌出を認めており，来列の状態を考虑したらえで保 存をできるだけ㾍先させるべきであるとの感触を得てい る.

萌出空隙の確保については，われわれも2 例において 床保隙装置を使用しているが，適用については，埋伏菻 の萌出が速いことから, 必ずしも全例に用いる必要はな く，埋伏歯が低位の場合，もしくは捛胞が大きく第一大 曰歯の骨植に影響が予想される場合，上下の第一大臼崡 の咬合が不安定な場合など, 特殊な場合についてのみ適 用を検討すべきであると思われた。

原因埋伏歯の幽根の完成度については，野間ら ${ }^{8)}$ や内 藤ら ${ }^{9)}$ の粦根の完成した埋伏歯の開空療法は適用外であ るといら意見と，工藤 $5^{4)}$ や富永 $5^{6)}$ の歯根完成歯の萌 出をみたといら意見に分れている．今回われわれの経験 した症例では，歯根形成の完了したものがないので，こ の点については検索しえなかったが，崡根形成がぞの段 階の症例に扣いても萌出状況に差は見られなかった。

整胞の大きさと埋伏歯の傾斜度については，X線写真 によりある程度までは術後の埋伏歯の萌出状熊を予測す ることができるとの感触が得られた。今回の検索では，

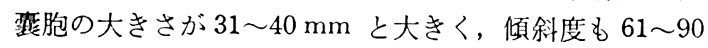
度と大きな症例が 2 例あり, 両症例とも萌出後に著しい 料軸の捻転を認めた。また，洯胞の大きさが $41 \mathrm{~mm}$ 以 上と大きくとも傾斜度が $0 \sim 30$ 度の症例では歯軸の念転 を起こしていないことから, 傾斜の強い症例では歯軸の 捻転を引き起こしやすいと考えられた。しかし，このよ らな捻転を起こした症例でも萌出位置は正常歯列内にあ り，著しい谖生は見ていない。

原因埋伏将の萌出速度は健侧に比べ明らかに早いとい ら結果を得た。その理由として Fanning ${ }^{10)}$ が報告してい るよらに, 骨の存在の有無, また, 小柴ら ${ }^{11)} の$ 報告によ る開空療法による踓胞腔の減圧効果が影许していると推 測される。

治癒状態については, 術後 6 か月から 1 年で骨梁の確 認できた症例は17例中10例であった，他の 7 例はこの期 間に経過微察できなかった症例であるが，その後の観察
で骨梁の確認をしており，この結果よりほぼ 6 か月から 1 年で治㾏に至ると考えられた。富永ら ${ }^{6)}$ は術後 $3 \sim 6$ か月で周囲の骨質に近い状熊にまで骨化すると述べてい るがこの違いは判定規準の差によるものと考えられる.

また，全症例に扣いて病理組織検査を行った結果，摘 出物の腫瘳性病変の可能性は否定されており, 再発傾向 も認めていない.

佐藤ら゙)は, 開空術で得た組織の病理組織検査の徹底 と十分な経過観察を行らことによって，X線透過像を示 寸他の腫瘕性病変との鑑別を合わせ行えば，開空療法は 小見の滤胞性雪缼胞の根治療法となりらると報告してい るが，今回の症例検討によりわれわれも全く同様に感し ている.

また，矯正治療に関しては，今回報告したような直径 20〜40 mm 程度の症例においては適用に必要性を感じ

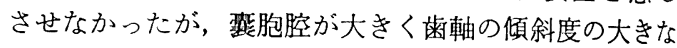
症例については，その適用についてはさらに検討を加兄 る必要があると考えている。

\section{結論}

小児の含歯性繁胞17症例に対しX線写真と臨床所見を 用い, 術前の原因埋伏歯, 簍胞および骨の状態之術後経 過との関係を分析考察したが，全例において原因埋伏歯 列内に萌出しており，小韭の含歯性留胞に対する開空療 法は，原因埋伏歯の保存に非常に有効な手段であると考 えられた。しかし，原因埋伏歯の傾斜が強い症例では㐪 軸の捻転を生じ, 術中術後の矯正治療の必要性が示唆さ れた。

本論文の要旨は，昭和63年 5 月 15 日，第13回日本口腟 外科学会中部地方会（於伊勢）において発表した。

\section{引用文 献}

1) Russell, A.Y.: Conservative management of bone cyst in children and adults. J Am Dent Assoc 23: 1719-1725 1936.

2) Moorrees, C.F.A., Fanning, E.A., et al.: Age variation of formation stages for ten permanent teeth. J Dent Res 42: 1490-1502 1963.

3) Welander, U., McDavid, W.D., et al.: Imaging characteristics of seven panoramic X-ray units. Dentomaxillofec Radiol Supplementum 8: 45501985.

4) 工藤逸郎, 田中博, 他: 溜胞性幽亦胞に対与 る開空療法の 6 例. 日大柬学 53: 379-389 1975.

5）任藤建夫, 結城勝彦, 他: 開敀療法の適応と術 式. 日本宷科評論 435：135-144 1980.

6）富永和広, 喜久田利弘, 他 : 閏空療法による小

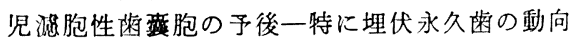


について一. 日ロ外誌 34: 133-138 1988.

7) Thoma, K.H.: Oral Surgery 2.5 th Ed, Mosby Co, St Louis, 1969, p 891-904.

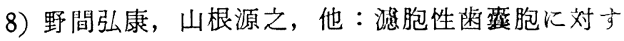
る開空療法の改良について.日口外誌 26：1336 13391980.

9) 内藤講一, 岡本善弘, 他 : 開空療法による整胞 内永久㴹誘導の 4 症例. 日口外誌 $30 ： 667-671$
1984.

10) Fanning, E.A.. Effect of Extraction of decideous molars on the formation and eruption of their successors. Angle Orthod 32: 44-53 1962.

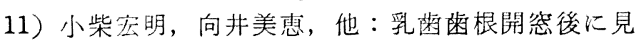

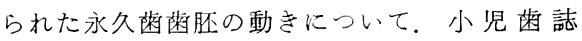
17: 118-122 1979. 